\title{
堆積層上における中・強震動の波群解析の試み
}

\author{
東京学芸大学教育学部地学教室 南島 正 重* - 山崎 謙介 \\ 東京大学地震研究所 工 藤 一 嘉 \\ (昭和 61 年 7 月 22 日受理)
}

\section{A Preliminary Analysis of Wave Groups Found in the Strong Ground Motion Records Observed on Sedimentary Layers}

\author{
Masashige Minamishima and Kensuke YamazakI \\ Division of Astronomy and Earth Sciences, Faculty of Education, \\ Tokyo Gakugei University \\ Kazuyoshi KUDo \\ Earthquake Research Institute, The University of Tokyo
}

(Received July 22, 1986)

In order to make clear the effects of sedimentary layer on strong ground motion due to earthquakes, a tripartite array with strong-motion accelerographs of three orthogonal components has been deployed since 1982 in the campus of Tokyo Gakugei University, Koganei, Tokyo. The array is located at the western suburbs of the Tokyo Metropolis on Pleistocene sedimentary layer which reaches ca. $2000 \mathrm{~m}$ depth overlying Pre-Tertiary basement. Digital accelerographs with sampling rate of $60 \mathrm{~Hz}$ and with $12 \mathrm{bits} /$ word are installed on the array of $300-400 \mathrm{~m}$ sides.

Several events among all the data acquired by the present time are available for analyses; those are in the magnitude range of $5.7-7.3$, in the depth range of $20-400 \mathrm{~km}$ and in the range of epicentral distance of $47-340 \mathrm{~km}$. Although the maximum height and the phase of high frequency acceleration are strongly affected by variety of surficial portions (thickness $\$$ $10 \mathrm{~m}$ ) underlying the foundations of seismographs, ground velocity and ground displacement of each station of the array show coherent signals with same amplitude but poorly discriminated phase lag each other up to the coda of the raw wave trains. However, filtrated waves of the raw data through some narrow pass bands exhibit clearly discriminated phase lags among the three stations throughout the wave trains right after the S-wave onset.

Method of sums and the Fourier's analysis are adopted to derive apparent velocities of the later phases which are of considerable amplitude in ground displacement and ground velocity; the frequency range of the phases is $0.2-1.0 \mathrm{~Hz}$ within which the velocity spectrum is in fairly high level. The results can be interpreted as surface waves excited in the thick sedimentary layer which covers the Tokyo area. Though the frequency dependence of phase velocity is clearly seen, it could not be confidently interpreted as a branch of unified single mode of surface wave. It is more likely to be interpreted as some branches of higher modes.

A moving-window analysis with multiple filtering technique has given time-varying frequency spectrum of the strong-ground motion wave trains. It also shows a sequence of average group velocities between seismic foci and the array station. The results in conjunc.

昭和 58 年 4 月 28 日, 昭和 59 年 4 月 5 日発表

* 現所属: 東京都立志村高等学校 
tion with those of the phase velocity suggest laterally heterogeneous surface layer in and around the Tokyo area.

\section{§1.はじめに}

強震動を任意の地点に対し正確に予測するためには，強震動を構成する個々の要素を解明し， 体系化する努力が必要である. その手始めとして, 観測された中・強震動に見られる波群を識 別し，整理することを目的として解析を試みた。

強震動の予測手法は, 観測記象をシミュレートすることを通じて提案され, 近年多くの成功 例が報告されるようになつた。その中の一つとして, 正規モード解の重ね合わせが提案されて いる [HARTZELl et al. (1978), HASEGaWA (1974), KUdo (1978, 1980), SwaNGER and BOORE (1978) など]. 但し, HARTZELL et al. (1978) を除き, 周期数秒以上の地震動を中心 として議論されている. 本論では, より短周期の地震動が，モード解としての解釈が可能かと いら視点から解析を試みている.

関東平野西部に位置する東京都小金井市に中・強震動を対象とした小規模な 3 点観測網を設 け，位相速度の決定を試みた。観測点は，厚さ約 $2 \mathrm{~km}$ の堆積層上にあり，その堆積層が強震 動に及ぼす影響を探る目的を持つ。この 3 角網は当初, 脈動観測を目的として設置され [IKEGAMI (1963)], 脈動の位相速度として, 平均 $1.83 \mathrm{~km} / \mathrm{s}$ (周期数秒) を得ている. 強震動 に見られる波群と脈動（やや長周期の微動）の波動的性質との関係も興味のもたれるところで ある。

近年, 強震動記録を用いた位相速度の研究が進められるようになつた [BoLT et al. (1982), 木下 (1985, 1986), 武藤・他 (1981), 太田・他 (1981) など]. 種々の地震および異なつた地 盤条件でのデータを蓄積する段階にあると言えよう．本論は位相速度を決定する最小単位の観 測網による検討であるが，今後の研究の方向づけを探ろうとするものである.

\section{$\S 2$. 観測の概要}

東京都小金井市にある東京学芸大学構内に执いて, 中・強震動を対象とした一辺約 $400 \mathrm{~m}$ の 3 点観測網が設置され，1982 年 1 月より観測が開始された.

観測点の地表は厚さ $7 \sim 9 \mathrm{~m}$ の関東ロームが堆積し, 南方約 $750 \mathrm{~m}$ を注ぼ東西に走る国分 寺崖線により，低位の立川面と接する武蔵野面上に位置している。ローム層の下部には武蔵野 碩層, 浅海性の上総層群が続いている [貝塚 (1979)].

Fig. 1 a) は, 多田 (1982) が重力データと地震探査の結果 [嶋・他 $(1976 \mathrm{a}$, b)] 等を総合 的に評価して求めた地震基盤（ $P$ 波速度が $5 \sim 5.5 \mathrm{~km} / \mathrm{s}$ ）面までの等深線（図中 1 ）である. これによると, 観測点 (KOG と総称する) 付近の基盤は深さ約 $2000 \mathrm{~m}$ に位置し, 大局的に は東に傾斜している．Fig. 1 b) に観測点配置と観測点記号を示す．P点を基準観測点（北緯 $35^{\circ} 42^{\prime} 07.4^{\prime \prime}$, 東径 $139^{\circ} 29^{\prime} 37.9^{\prime \prime}$, 標高 $74 \mathrm{~m}$ ) として, 東方 $410 \mathrm{~m}$ の地点に $\mathrm{Q}$, 北北東 325 $\mathrm{m}$ にRの 3 点で構成されている.

各観測点に固有周波数 $f_{0}=3.0 \mathrm{~Hz}$, 減衰定数 $(h)=22$ の動コイル型地震計 3 成分（上下； 1 , 水平；2）が設置されている， $\mathrm{Q}, \mathrm{R}$ 点の地震計出力は地下ヶーブルにより $\mathrm{P}$ 点で集中的に記 録されるシステムになつている. 信号は 5.7 秒間の遅延回路を経て $60 \mathrm{~Hz}$ のサンプリングで 


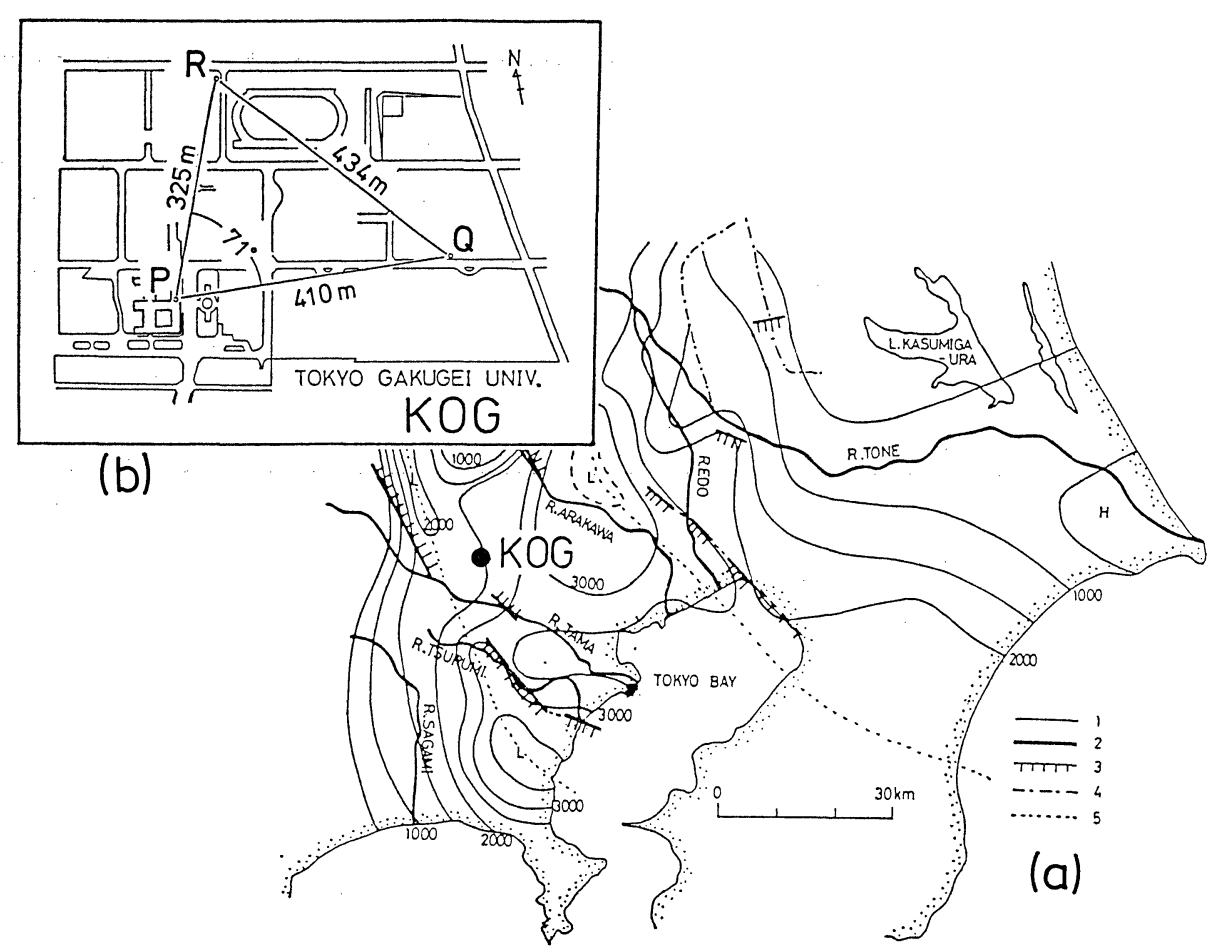

Fig. 1. a) Structure of the basement beneath the Kanto plain after TADA (1983) and the location of KOG station. 1: Contour line, 2: River, 3: Fault in basement; 4: Karasuyama-Sugonuma fault, 5: Axis of subsidence in basement. b) Configuration of the tripartite array at KOG.

12 ビット 1 語のディジタルデータとしてカセットテープに記録される (DACS-9101L: マーク ランド製)． 3 点の同時サンプリングを行うため， 1 台からの基準信号に他 2 台を同調させる システムになつている (マスター・スレーブ方式). 周波数特性は $0.1 \sim 10 \mathrm{~Hz}$ の間で加速度 平坦 $( \pm 1 \mathrm{~dB})$ となつており, 記録可能な最大值を $300 \mathrm{gal}$ に設定してある.

\section{§3. デ 一 タ}

Table 1 に示す 4 地震の記録を解析した。 以下，本論では簡便のため，各地震を $\mathrm{A}, \mathrm{B}, \mathrm{C}$, $\mathrm{D}$ と表わす. Fig. 2 に各地震の震央, 発生年月日, $M$ などを示す. 以下に各地震および記 録などの特徴を記す.

地震 $\mathrm{A}$ ：茨城県沖, 海溝軸内側のやや大きな地震 $(M=7.0)$ で, 東京の震度は 3 であつた. 3 地点で得られた加速度記象およびフーリエ変換法により求めた速度・変位記象を Fig. $3 \mathrm{a}$ に示す (トランスヴァース成分のみ). P 波初動から約 50 秒後にやや長周期の波が到来して いる．震央距離が長いため，振動継続時間が長いことなどが特徵的である．また計器の不調に より, P点の記録に中断が生じている.

地震 $\mathrm{B}$ ：相模トラフ近傍に発生した中規模の地震 $(M=5.7)$ で, 東京・横浜では震度 4 を 記録した． 神奈川・千葉両県で若干の被害が報告されている [茅野 (1982)]. 加速度・速度記 
Table 1. Earthquake parameters analyzed in the text

\begin{tabular}{|c|c|c|c|c|c|c|}
\hline Event & $\begin{array}{c}\text { Origin time } \\
D / M / Y \\
h, m, s\end{array}$ & $\begin{array}{c}\text { Epicenter } \\
\text { Lat. } \\
\text { Long. }\end{array}$ & $\begin{array}{c}\text { Depth } \\
(\mathrm{km})\end{array}$ & Mag. & $\begin{array}{l}\text { Distance } \\
\quad(\mathrm{km})\end{array}$ & Azimuth* \\
\hline \multirow[t]{2}{*}{ A } & $23 / 07 / 82$ & $36^{\circ} 11^{\prime} \mathrm{N}$ & 30 & 7.0 & 228.0 & $75.7^{\circ}$ \\
\hline & 232350.9 & $141^{\circ} 57^{\prime} \mathrm{E}$ & & & & \\
\hline \multirow[t]{2}{*}{ B } & $12 / 08 / 82$ & $34^{\circ} 53^{\prime} \mathrm{N}$ & 30 & 5.7 & 91.1 & $179.9^{\circ}$ \\
\hline & 133300.0 & $139^{\circ} 34^{\prime} \mathrm{E}$ & & & & \\
\hline \multirow[t]{2}{*}{$\mathrm{C}$} & $08 / 08 / 83$ & $35^{\circ} 31.1^{\prime} \mathrm{N}$ & 22 & 6.0 & 47.2 & $244.5^{\circ}$ \\
\hline & 124758.6 & $139^{\circ} 01.5^{\prime} \mathrm{E}$ & & & & \\
\hline \multirow[t]{2}{*}{$\mathrm{D}$} & $01 / 01 / 84$ & $33^{\circ} 37.2^{\prime} \mathrm{N}$ & 388 & 7.3 & 335.3 & $227.2^{\circ}$ \\
\hline & 180341.0 & $136^{\circ} 50.5^{\prime} \mathrm{E}$ & & & & \\
\hline
\end{tabular}

* Azimuth denotes the direction of the epicenters measured clockwise from the north.

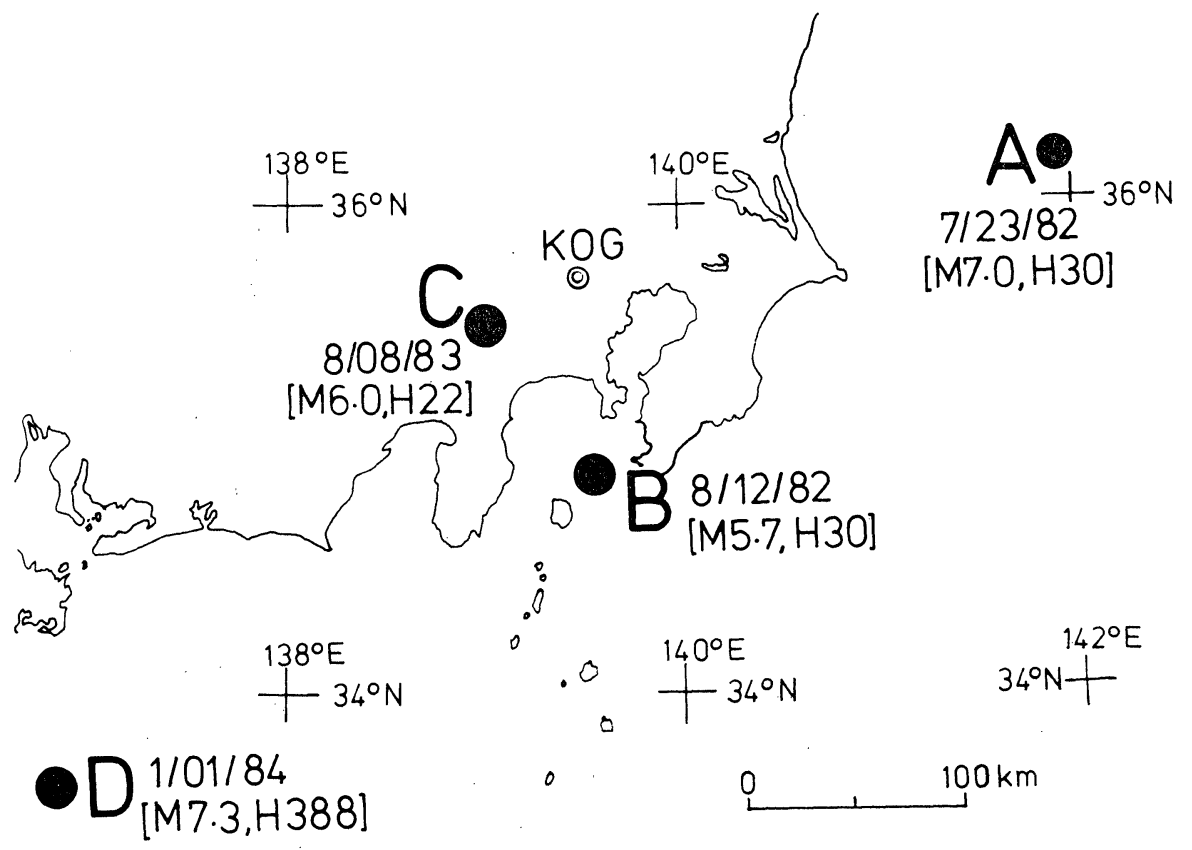

of

Fig. 2. Epicenters of earthquakes analyzed in the text.

象を Fig. $3 \mathrm{~b}$ に示す． S 波の立上りが鋭く，速度波形で見ると， S 波がパルス的形状を示し ている.

地震 $\mathrm{C}$ : 山梨・神奈川県境に発生した内陸の浅発地震 $(M=6.0$, 深さ $22 \mathrm{~km})$ である. 落 石による死者 1 名を含め，神奈川県西部を中心として若干の被害が発生した．東京での震度は 4 である. 本論で扱う記録の中で最も加速度值が大きく, 震央距離も短い. 加速度・速度・変 位記象を Fig. 3c に示す.

地震 $\mathrm{D}$ : 東海沖の深発地震で, 他の 3 地震と種々要素が異なる. 関東地方が異常震域となり, 


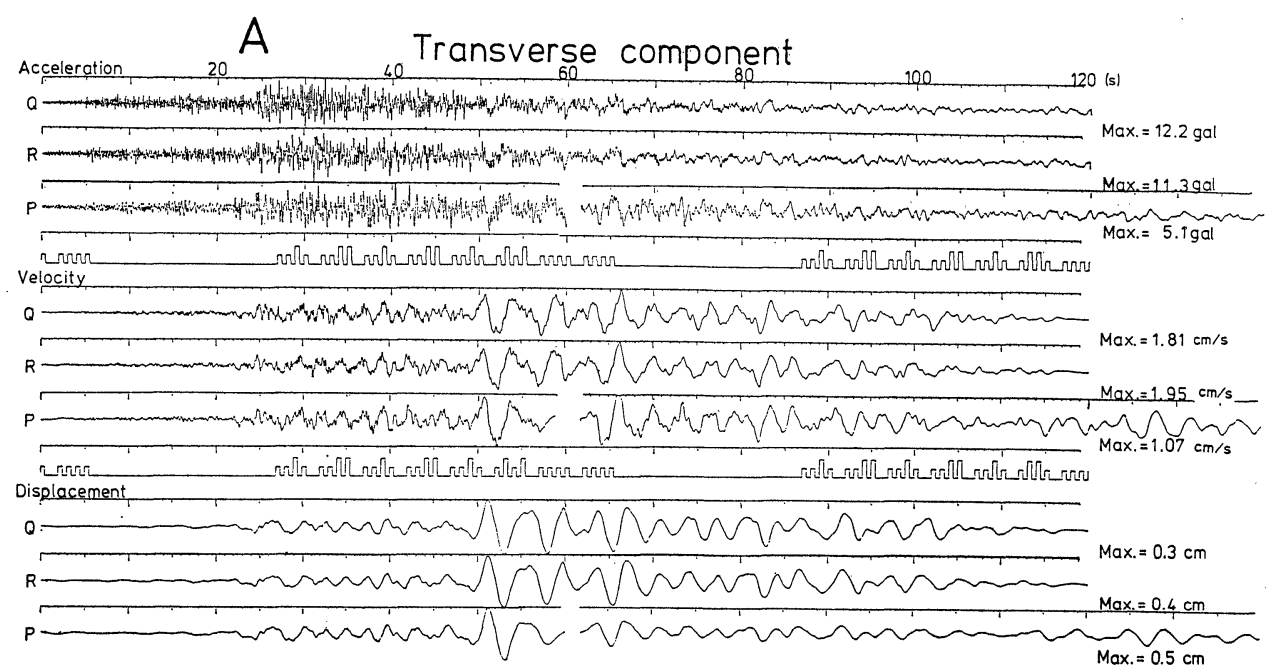

Fig. 3a. Transversely rotated seismograms for event A. Velocity and displacement seismograms are obtained through the Fourier transform of the raw accelerograms. Origins of the time axes indicate 5.7 seconds prior to the triggered time. Value of the maximum amplitude of each trace is placed at the end of the coda. Interruption of the traces at the point $\mathrm{P}$ is owed to some instrumental troubles.

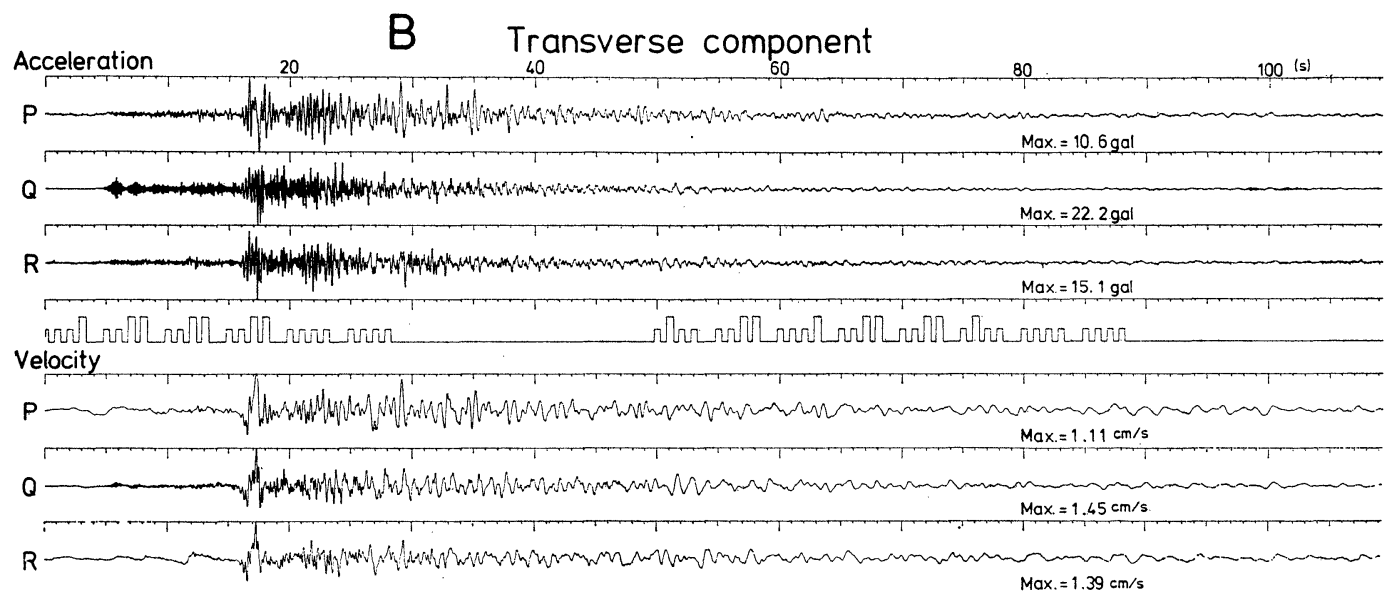

Fig. 3b. Transversely rotated seismograms for event B. Other notations are the same as Fig. 3a.

東京の震度は 4 であつた。 $M$ が大きかつたことと，震源距離が長いことから，振動継続時間 が長く，波形が複雑である. Fig. $3 \mathrm{~d}$ に加速度・速度記象を示す.

なお，全地震記録を通じて $\mathrm{P}$ 点の最大加速度は他 2 点に比べて小さい.これは， $\mathrm{P}$ 点が建物 内の地震計台に設置されていること, しかも地震計台が $7.5 \mathrm{~m}$ 下の砂碟層に達する杭に支持 されていることによる. 他 2 点はブロック造観測小屋の床に設置されている. 


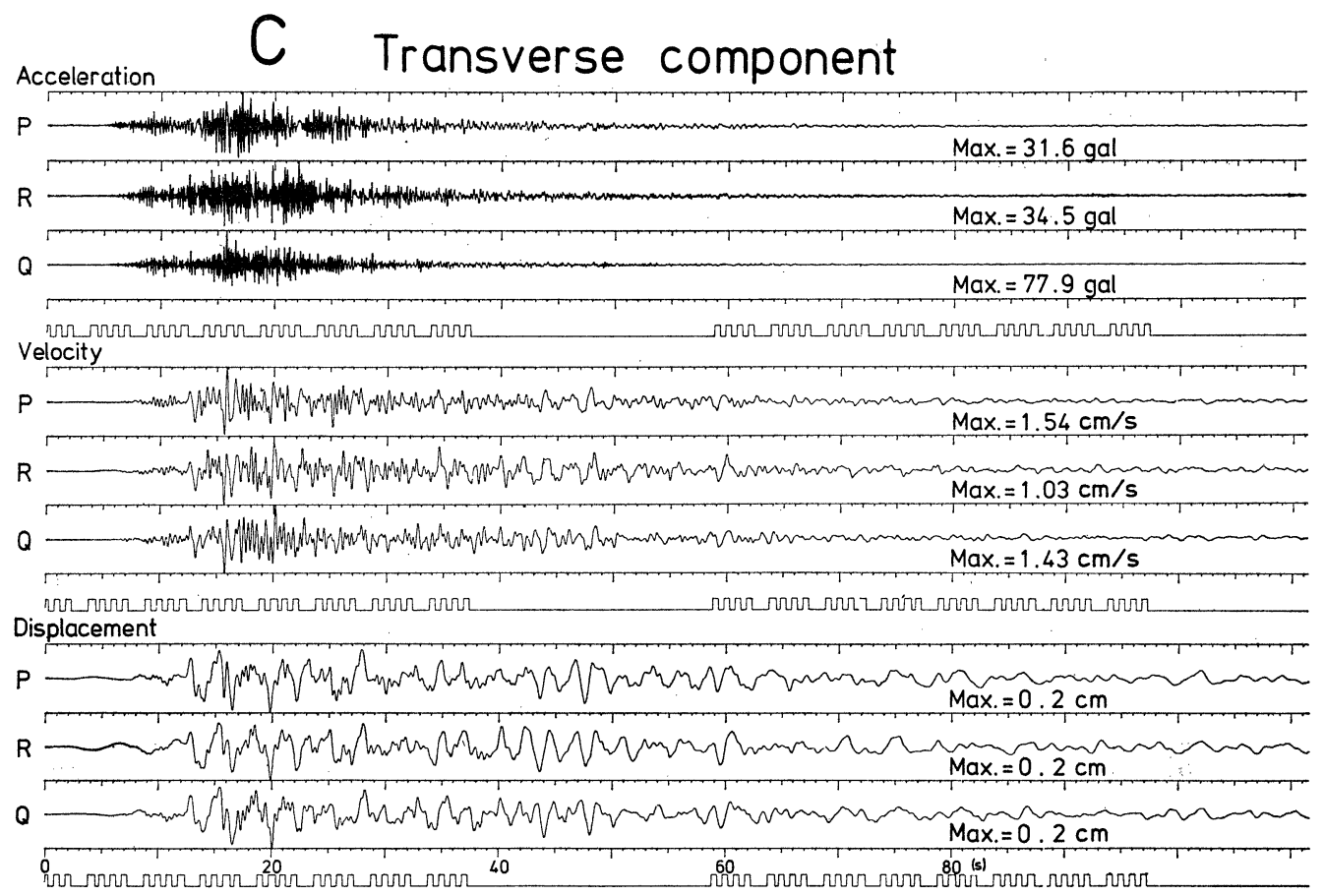

Fig. 3c. Transversely rotated seismograms for event C. Other notations are the same as Fig. 3a.

\section{Transverse component}

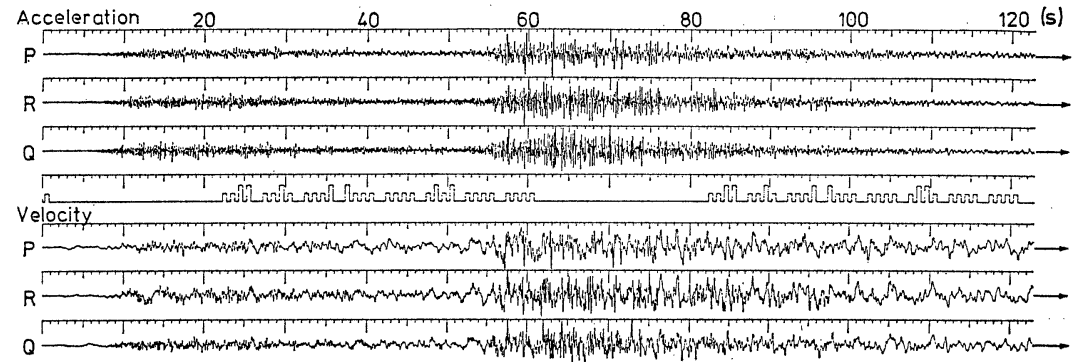

Max. $=10.9 \mathrm{gal}$

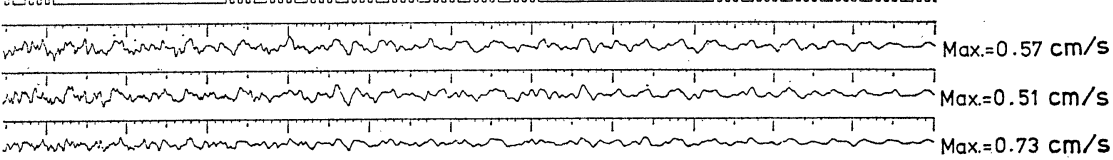

Fig. 3d. Transversely rotated seismograms for event D. Other notations are the same as Fig. 3a. 


\section{$\S 4$. 平均速度 (群速度)}

各地震の速度波形に対してムービングウィンドゥ，マルチプルフィルター法 [CARA (1973), DZIEWONSKI et al. (1969)] を適用し, Figs. 4〜8 のランニングスペクトルを求めた. Fig. 4 は地震 $\mathrm{C}$ に対し, 周波数 $0 \sim 6 \mathrm{~Hz}$ の広い帯域で得た結果である. 主要なエネルギーが平均速 度 $3.0 \sim 1.5 \mathrm{~km} / \mathrm{s}$ に集中し，乙かも広い周波数帯にわたつている. 一方, $1 \mathrm{~Hz}$ 以下の低周波 では $1 \mathrm{~km} / \mathrm{s}$ 以下の波群も顕著であり，分散を示していると見られる波群もある．本論では， ぞこまで表面波として扱い得るかを1つの目的としていること，およびコヒーレンスの良い波 を対象とすることから $0.2 \sim 1.5 \mathrm{~Hz}$ の周波数帯に限つて着目する.

Figs. $5 \sim 8$ は各地震の周波数 $0.2 \sim 1.5 \mathrm{~Hz}$ のランニングスペクトルであるが，Fig. 5 を除 き, 各スペクトルは，3点から個々に求まつたスペクトルを相乗した結果である. 従つて, 相 乗されたスペクトルは，3 地点に共通する波群が強調されたものとなる. 言い換えれば、 コヒ ーレンスの良い波群のみを取り出していることを意味する．観測点に位相差があつても，ウィ ンドウの時間幅 (8 秒間) から考慮すると無視できる範囲である. 地震 $\mathrm{A} の$ 記録には，中断が 生じているので， Q点の記録のみから (Fig. 5a) と P 点の中断後の記録から得た (Fig. 5b) スペクトルを共に示す. Figs. 5 8 の図中の番号はスペクトルの極大值として現われる波群 に順に付したもので, 以降地震記号と合わせ A2, B5 のように個々の波群を表現する.

地震A（Fig. 5a，b）は速度波形（Fig. 3a）の顕著な立上がりから，群速度 $3.5 \mathrm{~km} / \mathrm{s}$ と

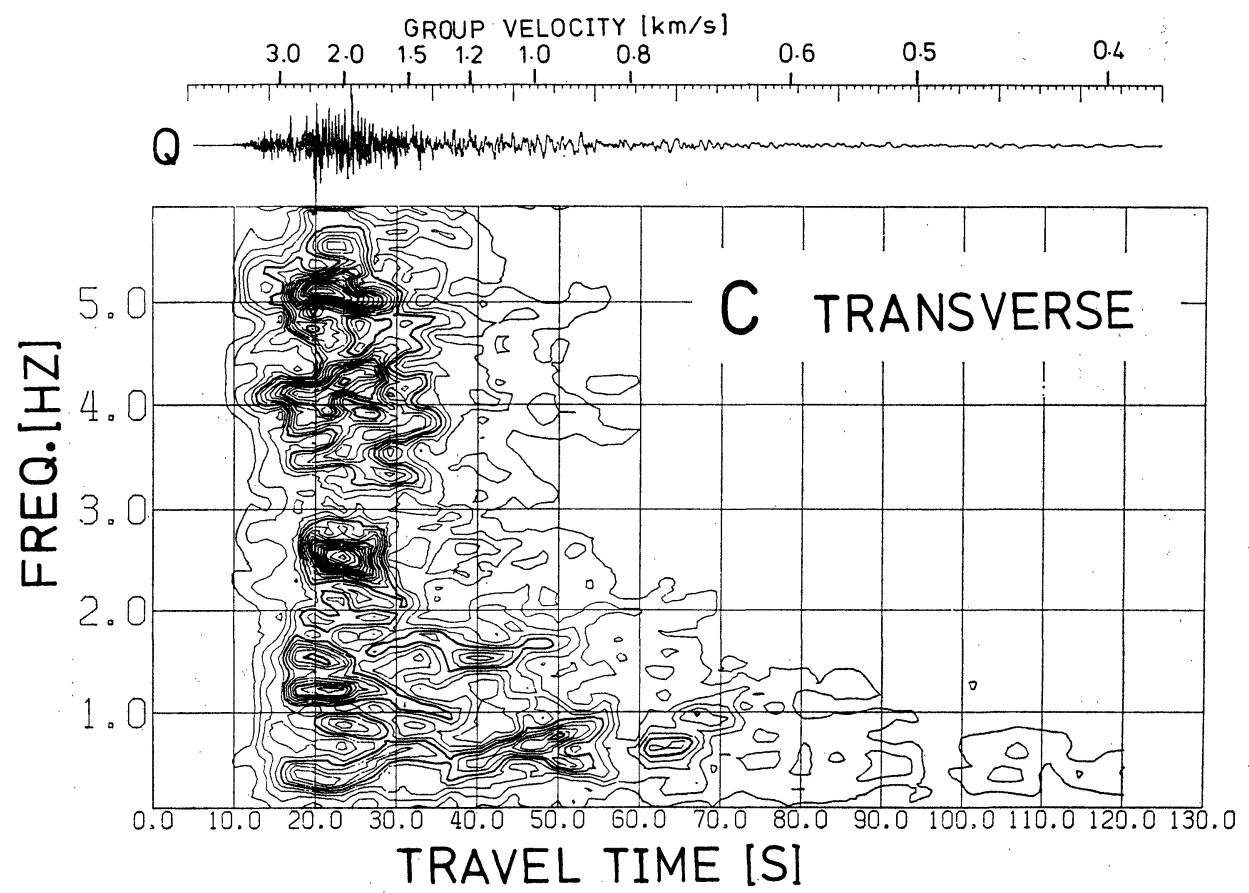

Fig. 4. Running spectra of ground velocity at the point $Q$ for the event C. Contour lines indicate relative height of Fourier amplitude. Group velocity in the top scale means average velocity between the epicenter and the station. 

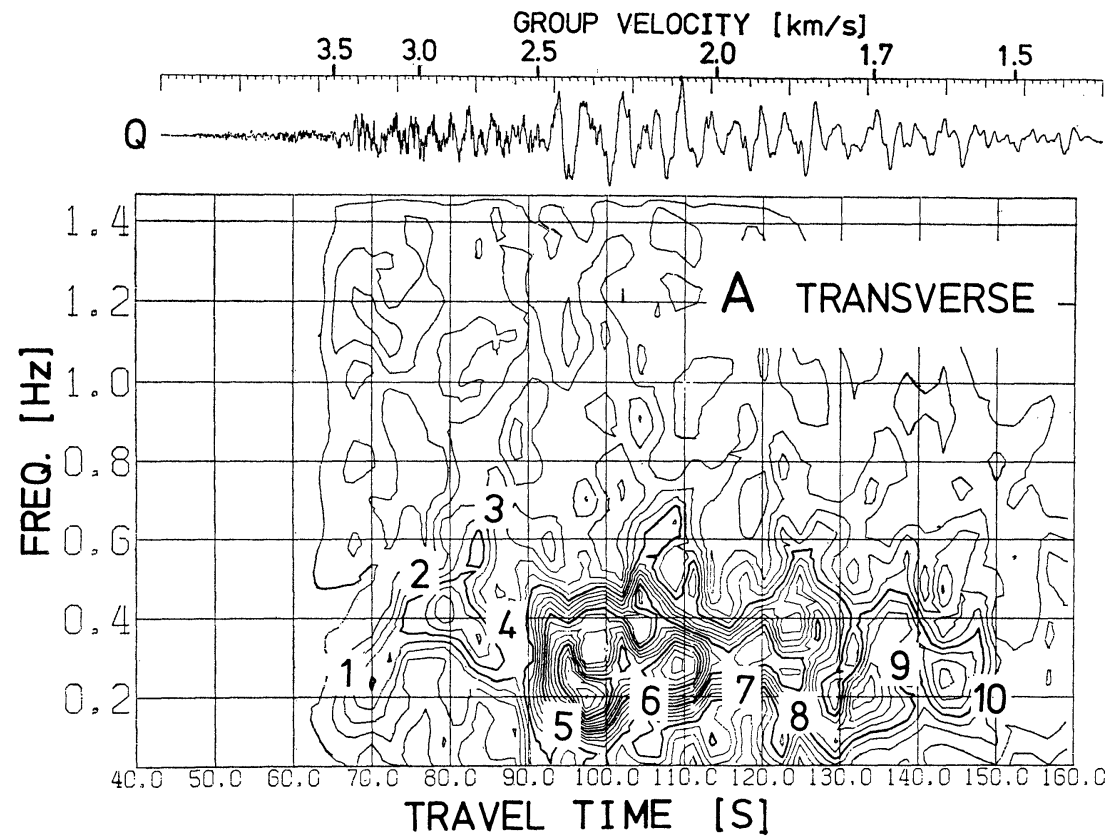

Fig. 5a. Running spectra of ground velocity for event A. Corresponding velocity seismogram is at the point $\mathrm{Q}$. The wave groups of relatively high energy in the frequencytime domain are numbered and labelled as 1,2 etc.; those are referred as A1, A2 etc. in the text.

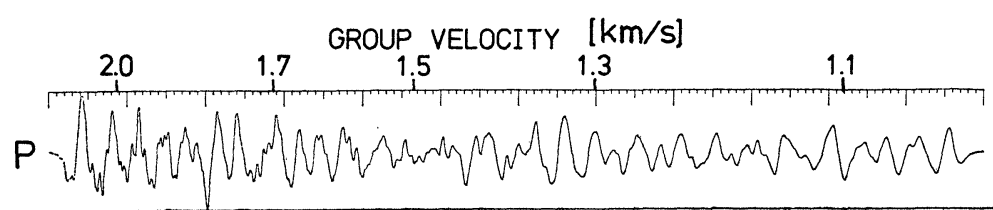

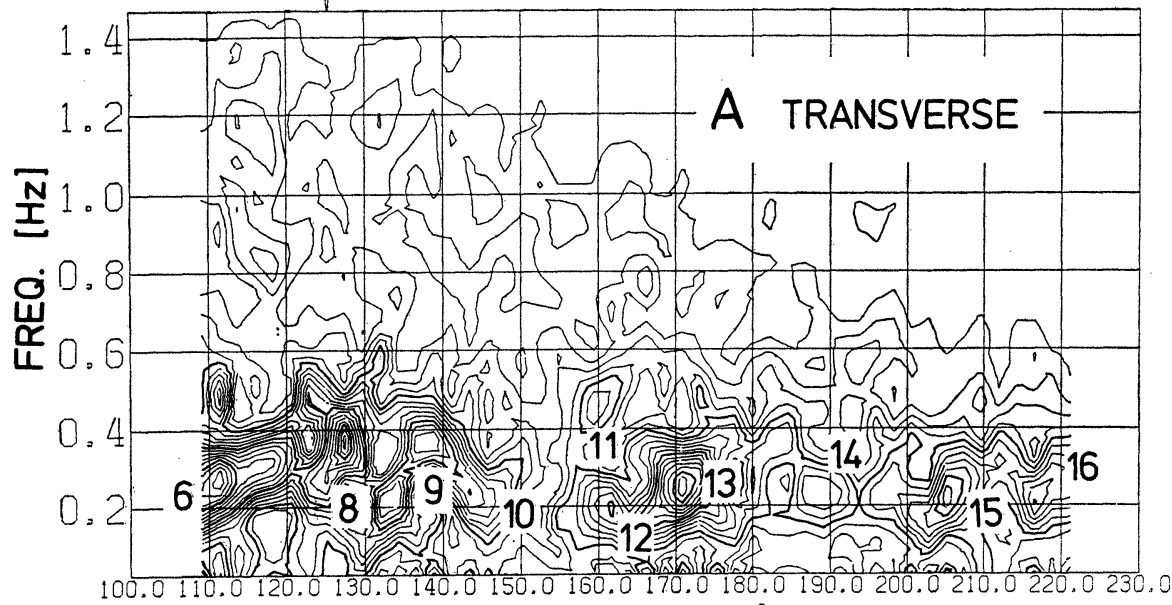

\section{TRAVEL TIME [S]}

Fig. 5b. Running spectra of ground velocity at the point $P$ for event $A$. This trace indicates later phases which succeeds to the early phases in Fig. 5a. Meaning of labels in the frequency-time domain are the same as Fig. 5 a. 

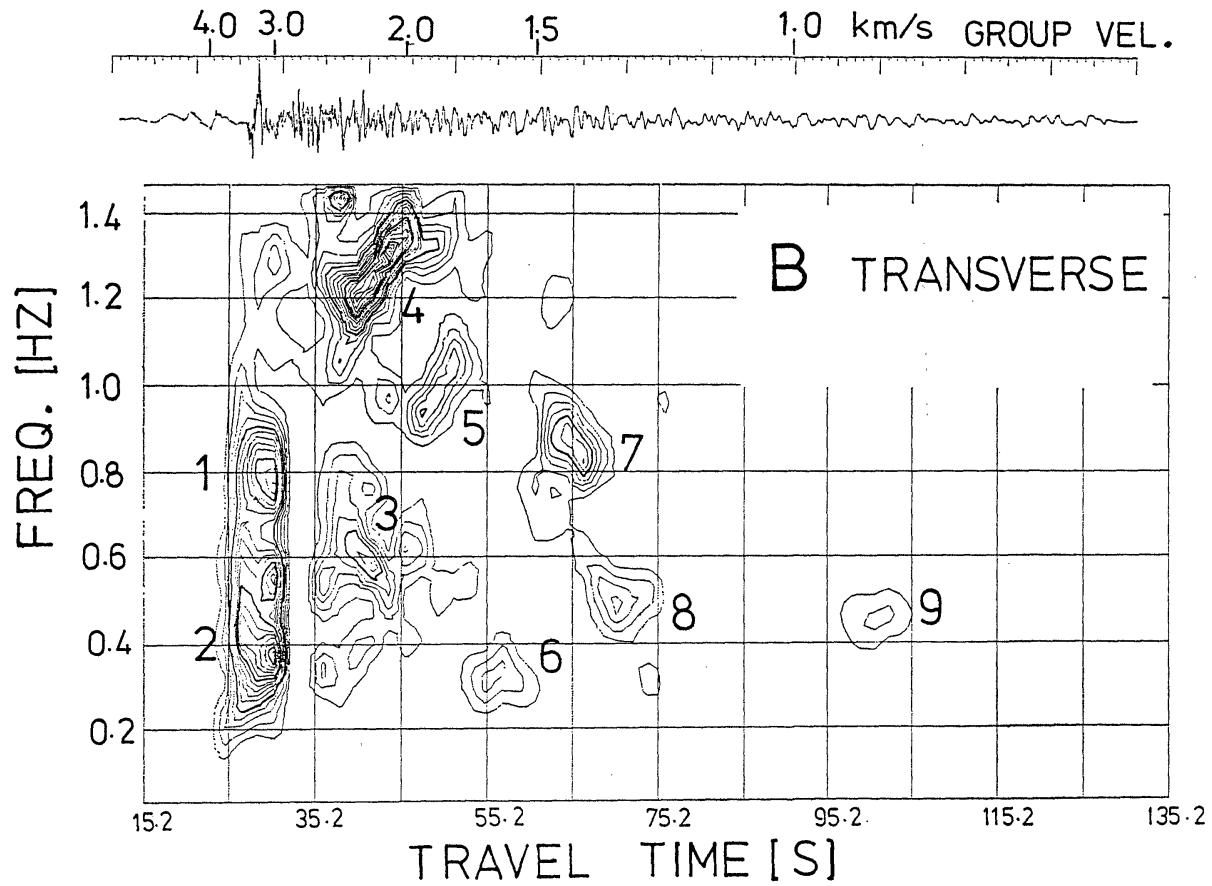

Fig. 6. Averaged running spectra at the array for the event $B$. The spectra are obtained through multiplication of velocity spectra of three stations. Velocity seismogram in the top trace is for the point $R$.

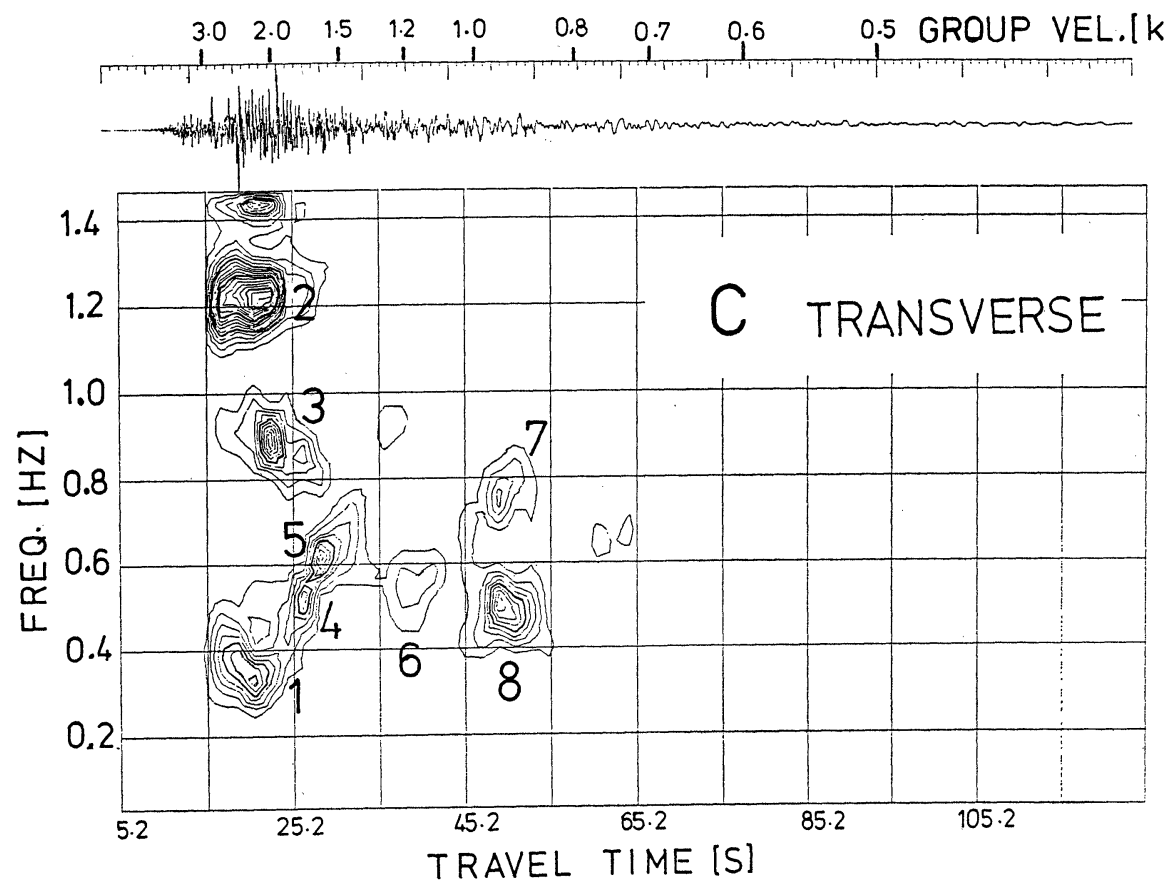

Fig. 7. Averaged running spectra at the array for the event $C$. Velocity seismogram in the top trace is for the point $Q$. 


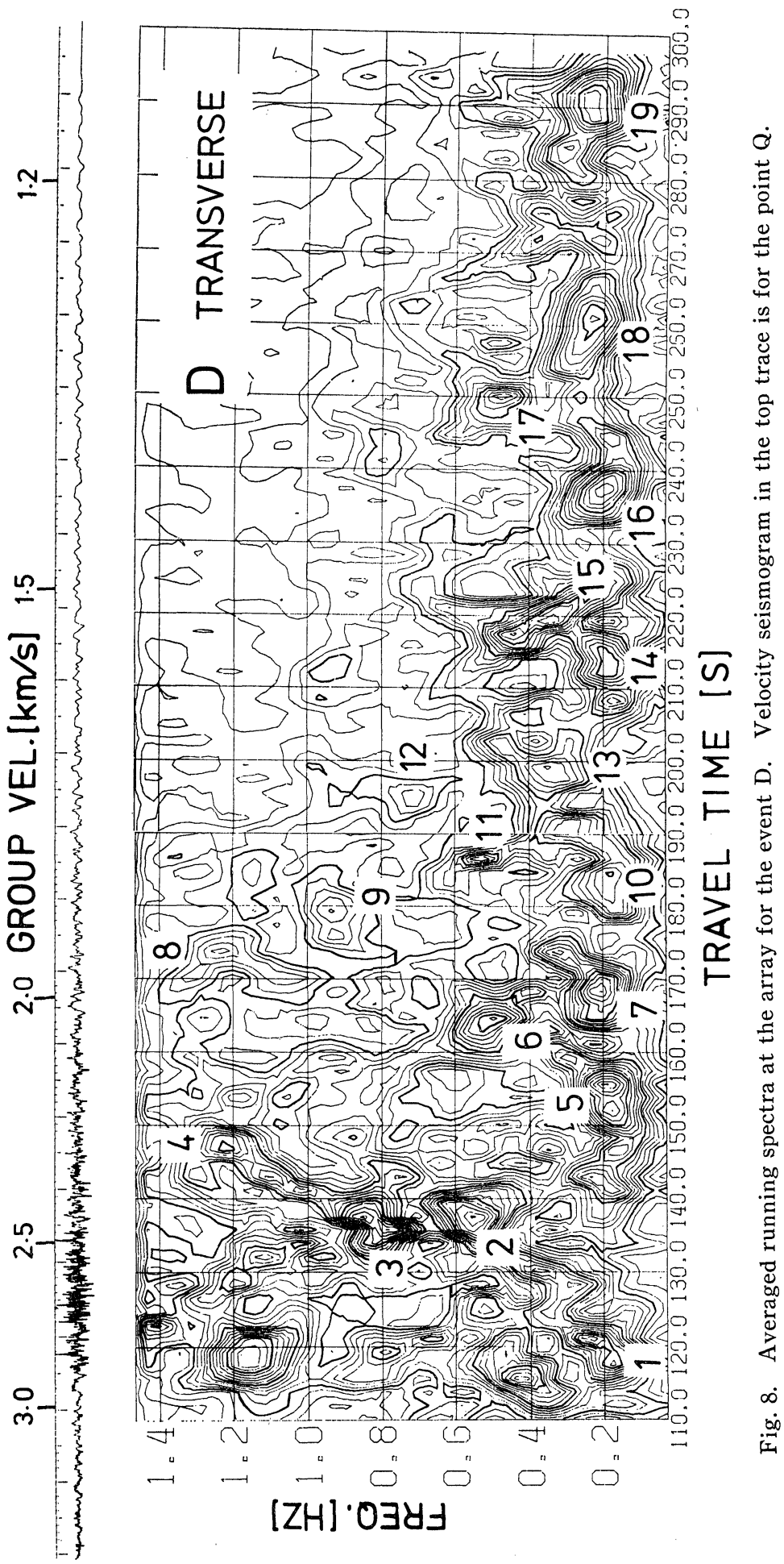


$2.5 \mathrm{~km} / \mathrm{s}$ の位相を読み取れる．従つて経路の異なる実体波として扱光ることができるが， $\mathrm{A} 1$ ， A2，A3，あるいは A5，A6 の連続した波群を分散性として把え得ることにる注目したい，地 震 Bでは B4，B5，地震 Cでは C4 から C5 の連続が分散性を示しているょうに見兄る.

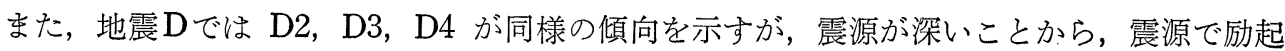
される表面波は小さい筈であり，他の地震とは異なつた考察が必要である.

\section{$\S 5 . \quad$ 位相 速度}

前節での波群がぞの種の波かを識別するためには，その位相速度が有力な情報となる，前節 で求まつた波群の速度は, 震源から観測点までの平均群速度に相当し, Fig. 1 から理解され る上らに, 水平方向に不均質な構造を考慮する必要性が示唆される。一方, 位相速度は傾斜層 がゆるやかであれば，直下の構造の反映とみなして良い [YAMAZAKI and ISHII (1973)] から， 少なくとも観測点直下の堆積層によつて励起された波の議論有効である. Fig. 9 は，バン ドパスフィルターの中心周波数を変光た出力結果を示してあるが， 3 点間で波形の相関が良く， 位相差も顕著な波群が見られる。

位相速度の決定には BLOCH and HALES (1968) に上る Method of Sums (以降 MS 法と 呼ぶ）飞準拠した方法を適用する. Fig. 10 飞解析の流机之概念を示す．P点の記録を基準と して， $\mathrm{Q}, \mathrm{R}$ 点の記録の時刻をそれぞれ $t_{1}, t_{2}$ だけずらして 3 波形を加兄合わせ，着目する 波群のフーリエ振幅を求める. この手続をを繰り返し, 振幅が最大となる $t_{1}, t_{2}$ から位相差を 決める．計算の度に異なる $t_{1}, t_{2}$ を設定することは，位相速度と到来方向をその都度仮定して いることを意味する，そこで，トランスヴァース成分を求める座標変換を，仮定する $t_{1}, t_{2}$ の 組及合せ毎に行つた後に MS 法を適用している.

計算結果の一例を Fig. 11 に示す. 本図は, $t_{1}$ と $t_{2}$ の様々な組み合せに対して計算された 振幅值を周波数毎に正規化して表現している (最大値は図中に *** で示す). 中心周波数に伴 つて位相差が变化していることから，波の分散性を読及取ることができる.

この方法の利点は, 到来方向と位相速度を同時に決定できること, フーリエ振幅の $t_{1}, t_{2}$ に 対する分布から，解の信頼性を相対的飞評価できることなどがある，一方，計算処理の時間が 長いこと, Radial 成分が優勢の時, 到来方向が $90^{\circ}$ 異なつた結果を与兄得るなどの問題点が ある. 後者の問題は, 大局的な Radial 成分のランニングスペクトルを参照して, 結果の採否 が検討される。なお，本観測網の広がりやサンプリング間隔の制限から，位相速度 $3 \mathrm{~km} / \mathrm{s}$ 以 上では分解能に乏しく, 波長が $400 \mathrm{~m}$ 以下の場合は議論の対象から除外した.

\section{§6. 結果と考察}

\section{1) 観測点直下の地下構造・分散曲線}

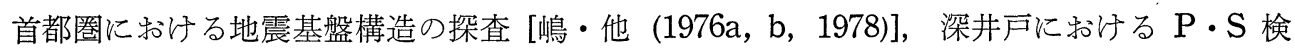
層 [山水・他 (1981)] の結果および MIKUMo (1966) の E-3A3 モデルを参照し, 観測点下の 速度構造を Fig. 12a のようにモデル化した．この地下構造モデルに基づく Love 波の分散曲 線 $\left(\mathrm{L}_{0} \sim \mathrm{L}_{4}\right)$ を Fig. $12 \mathrm{~b}$ に示す.

前節で求めた位相速度を地震毎に Fig. 13 亿示す。なお地震Aは記録の一部に中断がある ため, 対象から除き, 地震 $\mathrm{B}, \mathrm{C}, \mathrm{D}$ 飞限つて議論する. 安定した解として求まつた位相速度 
南島正重・山崎謙介・工藤一嘉

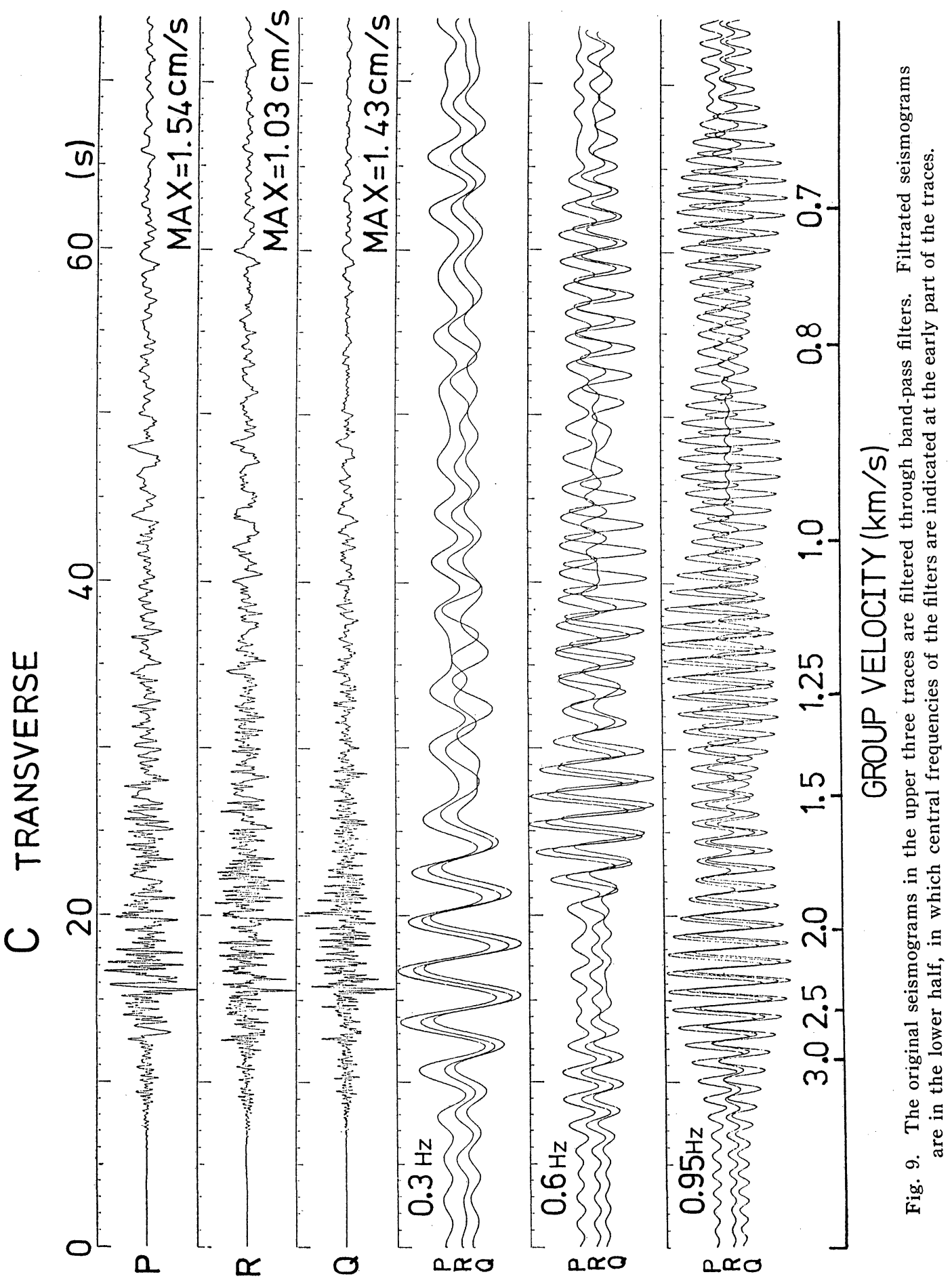




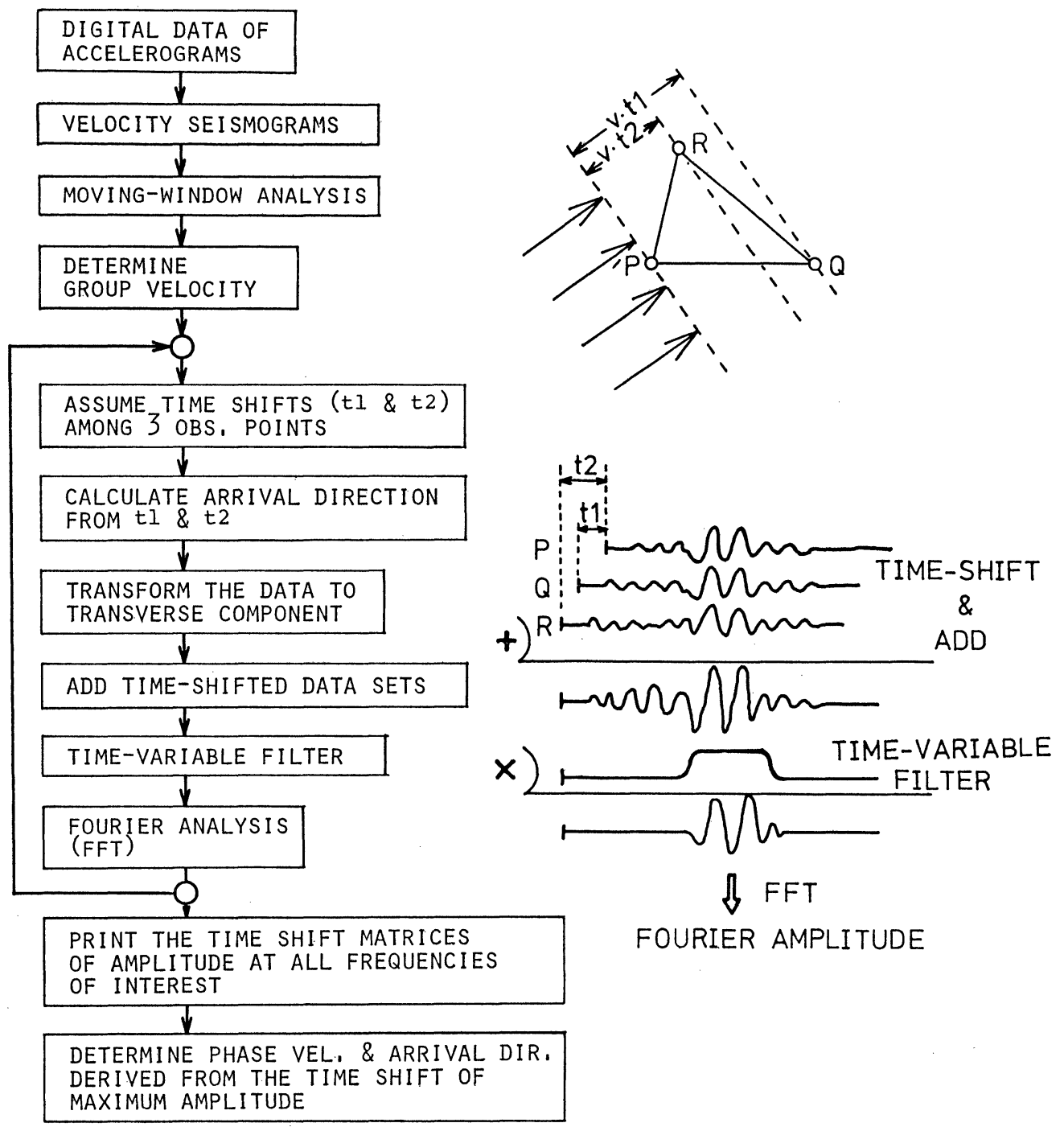

Fig. 10. Left; flow-chart of moving-window analysis and multiple-filtering. Right; plane wave arrival to a tripartite array (top) and an idea of "method of sums" for tpipartite array to calculate phase velocity and direction of wave approach (bottom).

Fig. 11. Next page. Top: matrix of phase velocity and direction of wave arrival corresponding to the combination of time shifts $\left(t_{1}\right.$ and $\left.t_{2}\right)$. Top and bottom of each row, respectively, indicate phase velocity in $10^{-2} \mathrm{~km} / \mathrm{s}$ and arrival direction in degree measured clockwise from the north. Others: matrices of Fourier amplitude corresponding to the combination of time shifts $\left(t_{1}\right.$ and $\left.t_{2}\right)$ for the frequency appeared on the left side. Elements of the amplitude matrices are normalized by the maximum values which are also placed on the left side. 


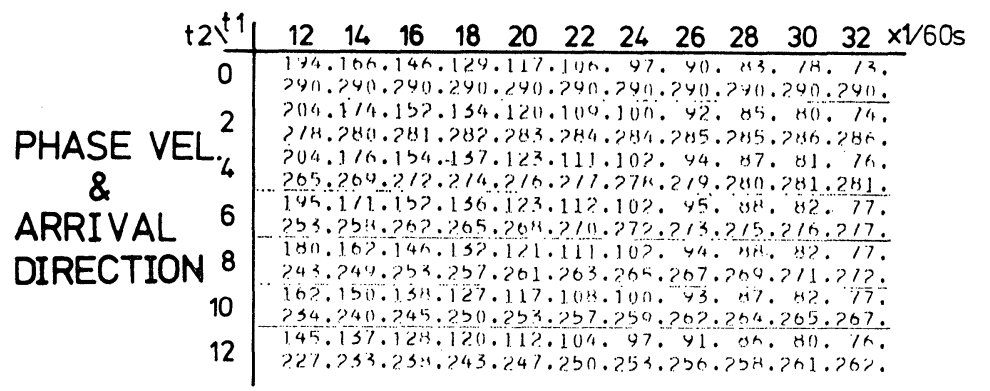

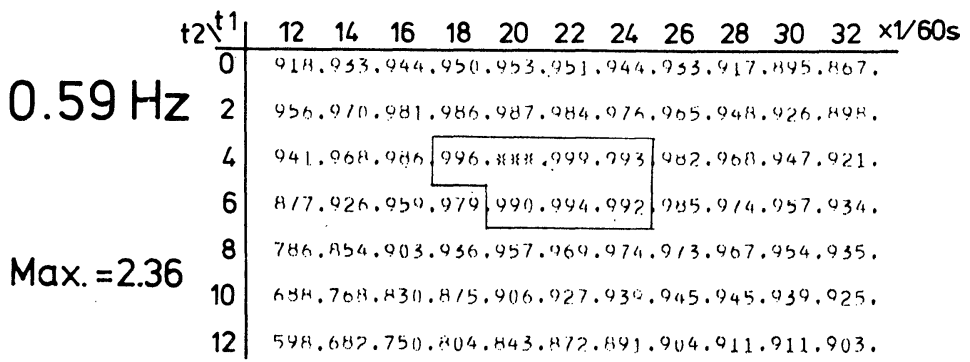

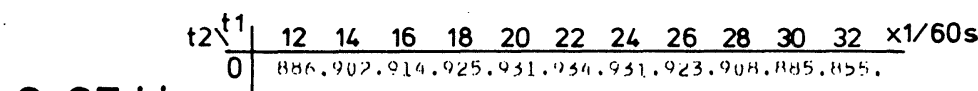

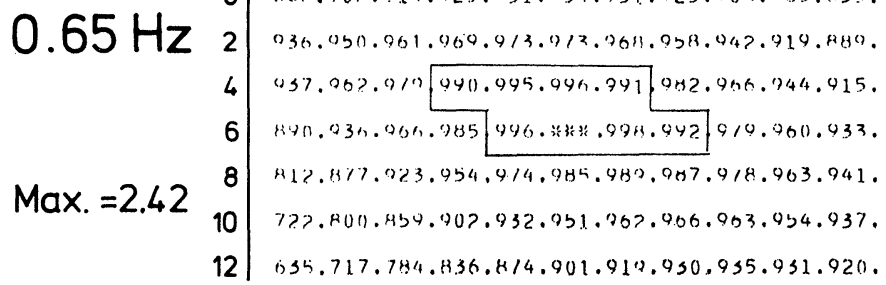

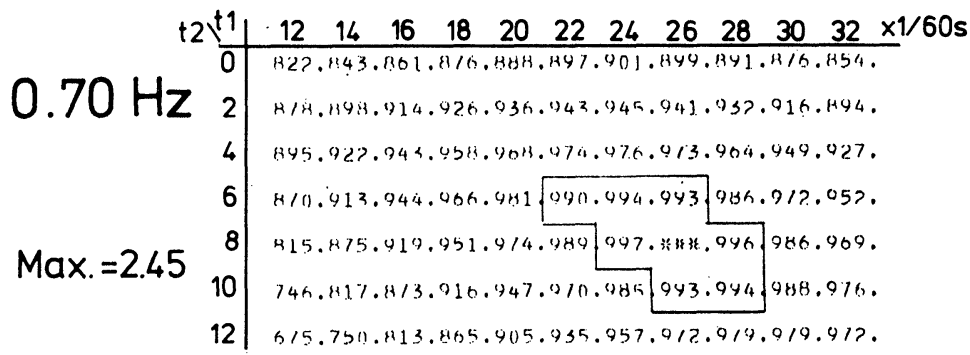

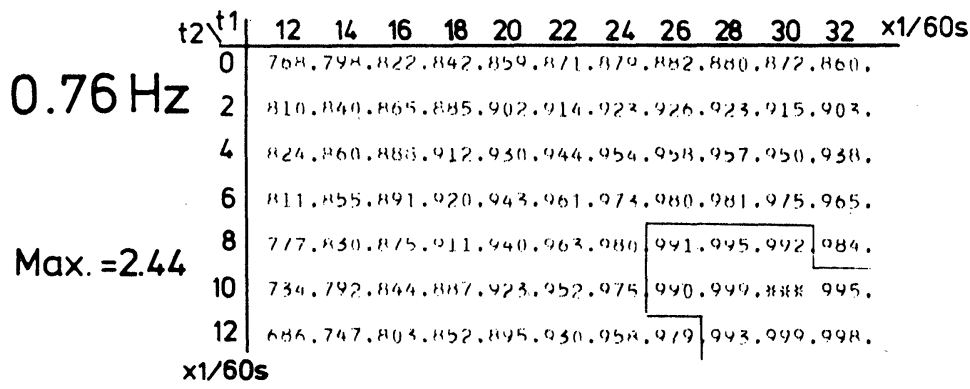




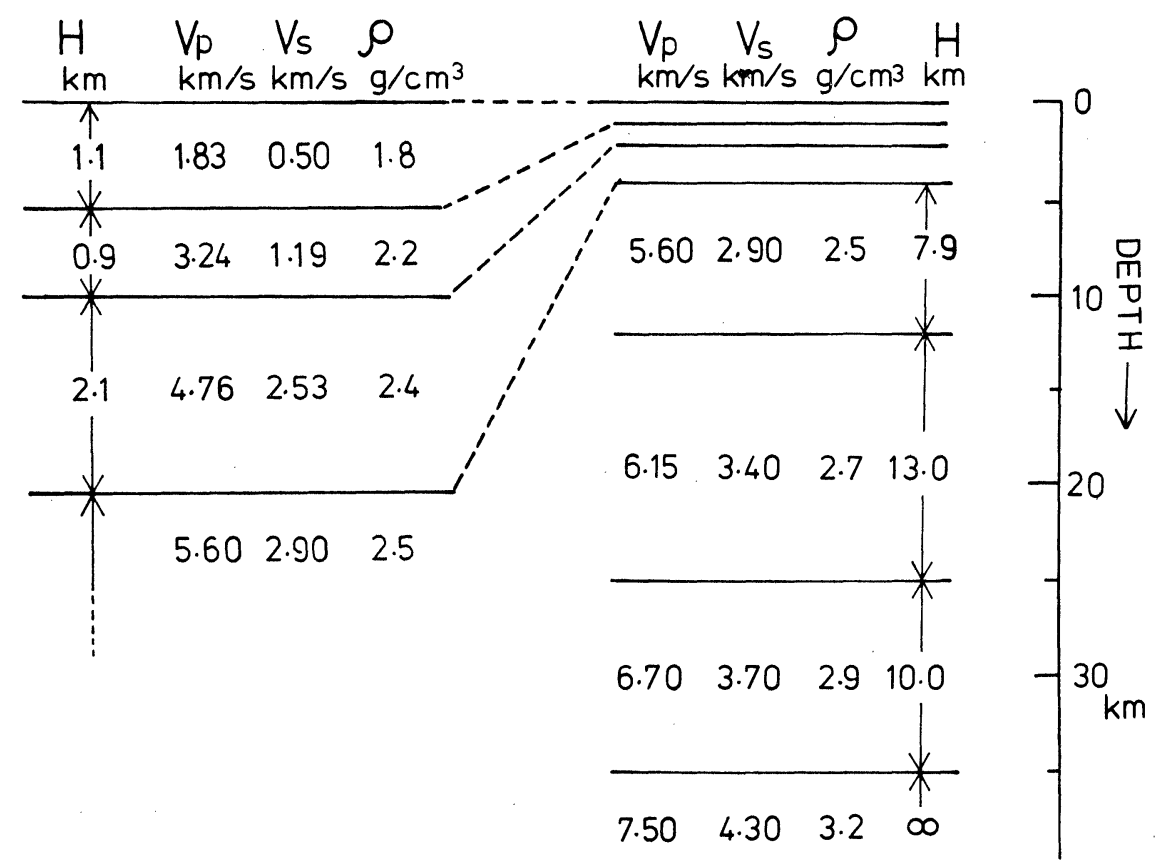

Fig. 12a. An assumed crustal structure beneath Kanto plain.

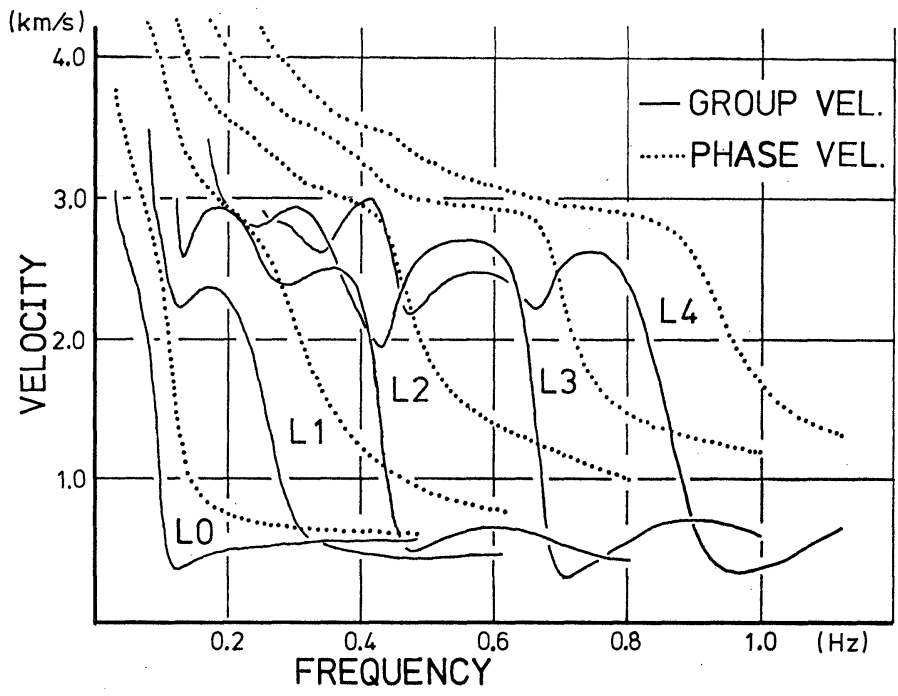

Fig. 12b. Dispersion curve of Love waves.

は, $3 \mathrm{~km} / \mathrm{s}$ 以上の值も散見されるが， $1 \mathrm{~km} / \mathrm{s}$ 前後あるいはそれ以下に決まつている例が多い。 速度の小さい堆積層内の伝播を反映した波群として理解できる. 位相速度と同時に求まる到来 方向は Fig. 14 に示すように，震央方向から大きくずれることはない，記録から得た位相速 度は理論分散曲線と良く対応しているとは言い難いが，若干の分散性が見られ，またモードが 

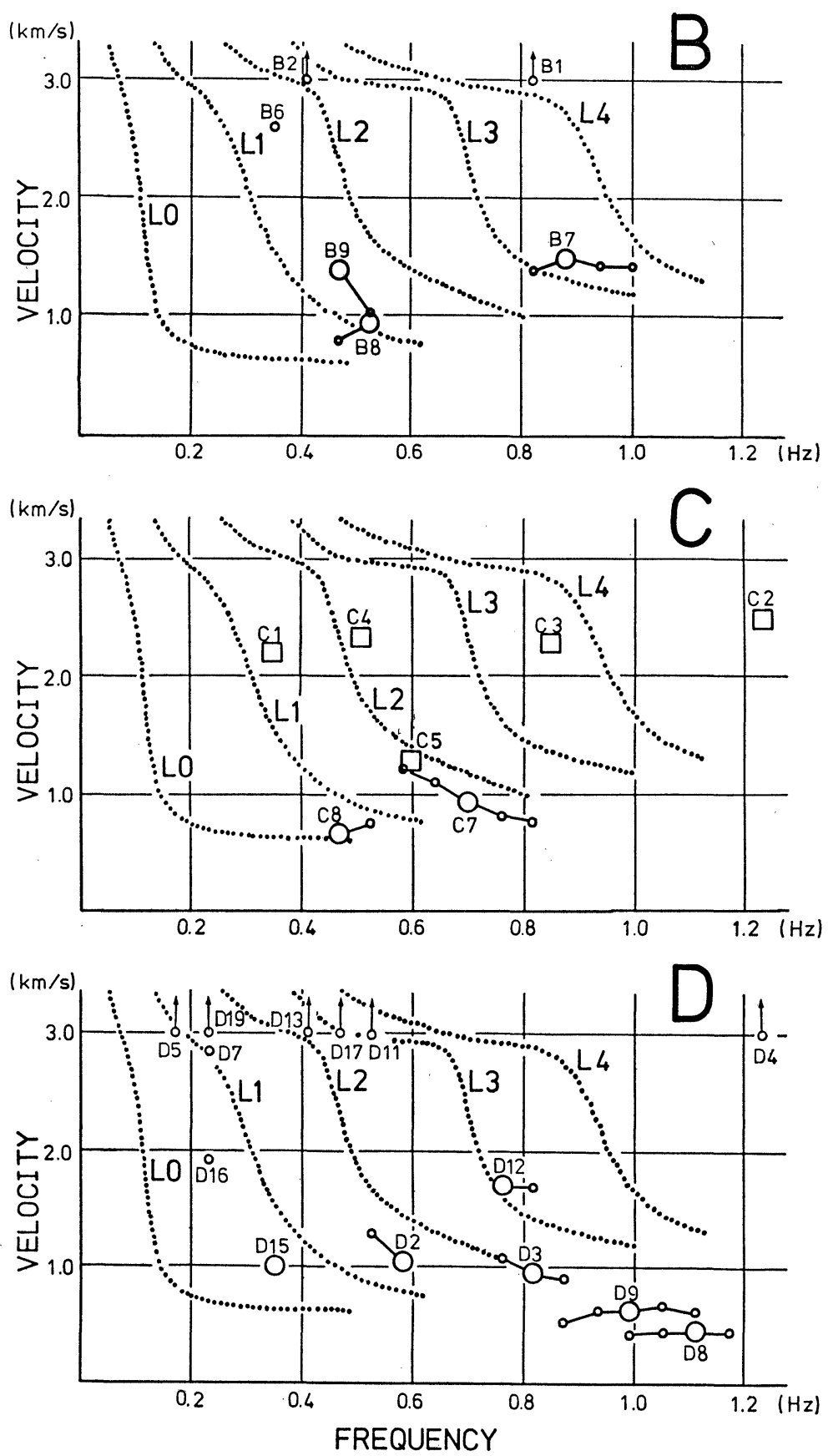

Fig. 13. Observed (open symbols) and theoretical (dotted curves) phase velocities. Large symbols indicate reliable values of high energy. Smaller symbols imply less reliable values due to less energy or unreasonably high velocity. Open squares for the event $\mathrm{C}$ indicate the results obtained by means of band-pass filtration. 


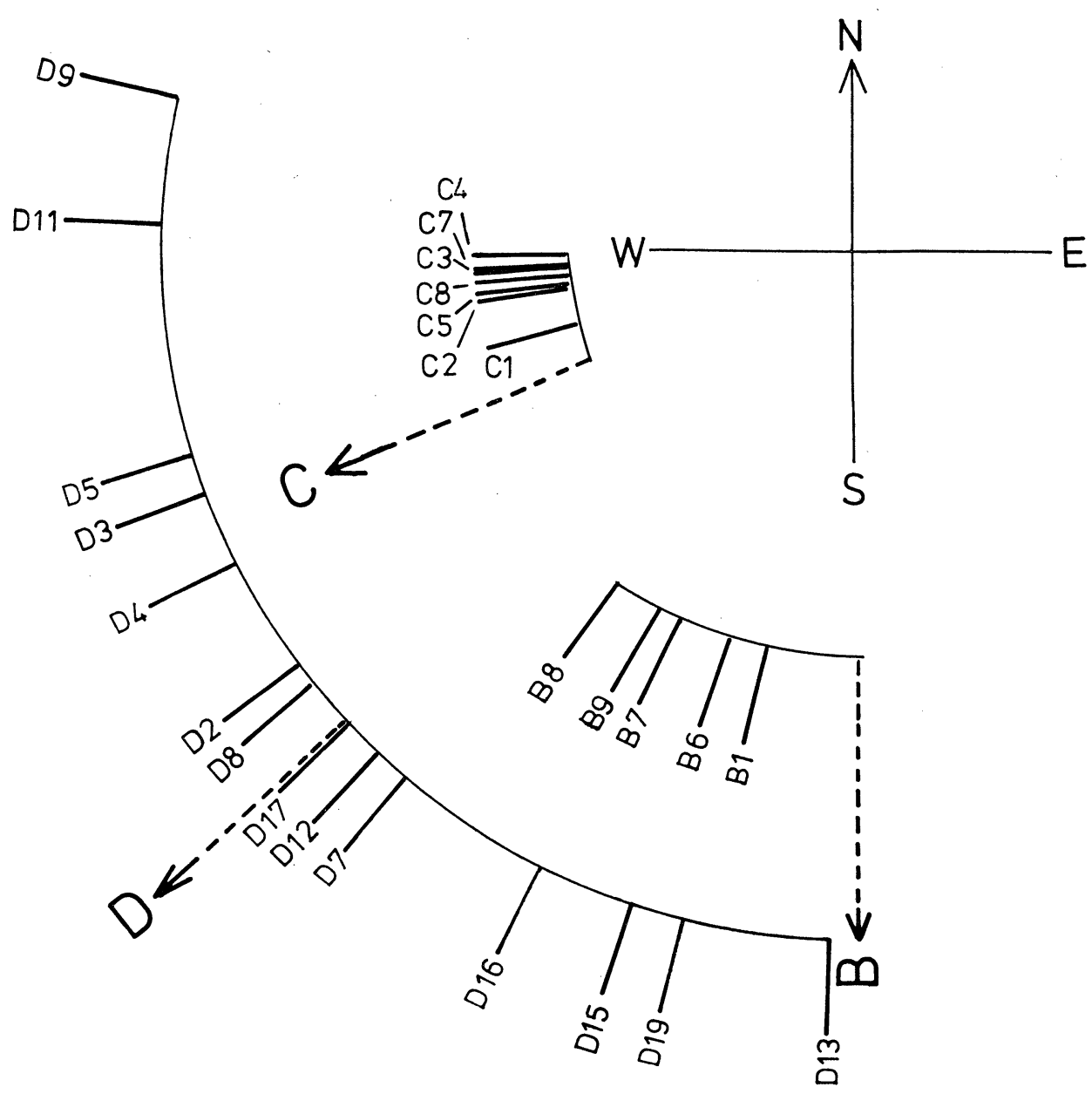

Fig. 14. Observed direction of wave arrival for wavelets in the frequency domain. Broken arrows indicate the directions of epicenters.

分離していると把えることも可能である. Fig. 13 の地震 Cの口印で示した位相速度は，MS 法ではなく, バンドパスフィルターを通過させた波形の山谷の走時差から求めた值である. $\mathrm{C} 1, \mathrm{C} 2, \mathrm{C} 3$ は位相速度・群速度共に $2 \mathrm{~km} / \mathrm{s}$ 強を示すため, 直接波と考えた方が理解し易い と言える. しかし，直接波はモードを形成する 1 つの構成波として把え得るので分散曲線上で の議論が可能である.なお，MS 法によつて決まらない位相速度がバンドパスフィルターによ る処理で求まることは, MS 法が, 限られた周波数帯に多くの波群が含まれている場合には, 必ずしも適切な処理法ではないことが同われる. 地震 $\mathrm{D}$ は震源が深く震央距離も長い, やや特 殊な地震である. 求まつた位相速度は, $3 \mathrm{~km} / \mathrm{s}$ 以上の高速度の波群と, $1 \mathrm{~km} / \mathrm{s}$ 以下の低速度 の波群の 2 つたきく別れている. 深い構造を反映した波群と, 堆積層の影響を強く受けた波 群が共に存在している. 


\section{2) 位相速度と平均群速度}

ランニングスペクトルから得られる群速度は震源・観測点間の平均的な構造を反映している. 一方, 位相速度は直下の構造を反映する. 各波群の位相速度, 平均群速度を Fig. 15 に示す. 各波群の半数以上は, 平均群速度が位相速度を上回り, 伝播方向の不均質構造を考慮しなけれ ばならない.この不均質構造を, 基盤露出地域と, 厚い堆積層地域の 2 地域に単純化し, 全伝 播経路に拈いて 2 地域の含まれる割合から平均群速度が求まる[佐藤 (1959)] ことを考慮して, 工藤・嶋 (1979), 田中・他 (1979) が，首都圈での堆積層の広がりを推定している．ただし， 周期 5 秒程度以上の $\mathrm{L}_{0}$ の波群が用いられている.

本論では, Fig. 12a に示した地下構造モデルで，第 3 層以浅の堆積層がない基盤構造を仮 定し, 同様の手法で構造の境界を求めた。ここで用いた波群は位相速度の決定精度が良く, 理 論分散曲線に調和する波群のみを採用した。結果を Table 2 および Fig. 16 に示す. 波群 B7，C7，C8 による結果は，大局的な地質構造や基盤構造探査 [嶋・他 (1978)] の結果などと 調和的である. 一方，地震 $\mathrm{D} に$ 対してはこの手法を適用することに問題があり，かつ波群を細 分化し過ぎたきらいもあり, 地震 $\mathrm{B}, \mathrm{C}$ の結果とは調和しない. 別途の考慮が必要である.

\section{3) 到来方向について}

位相速度と同時に求まる到来方向を Fig. 14 に示す. 破線が震央方向を表わすが, 地震 B,

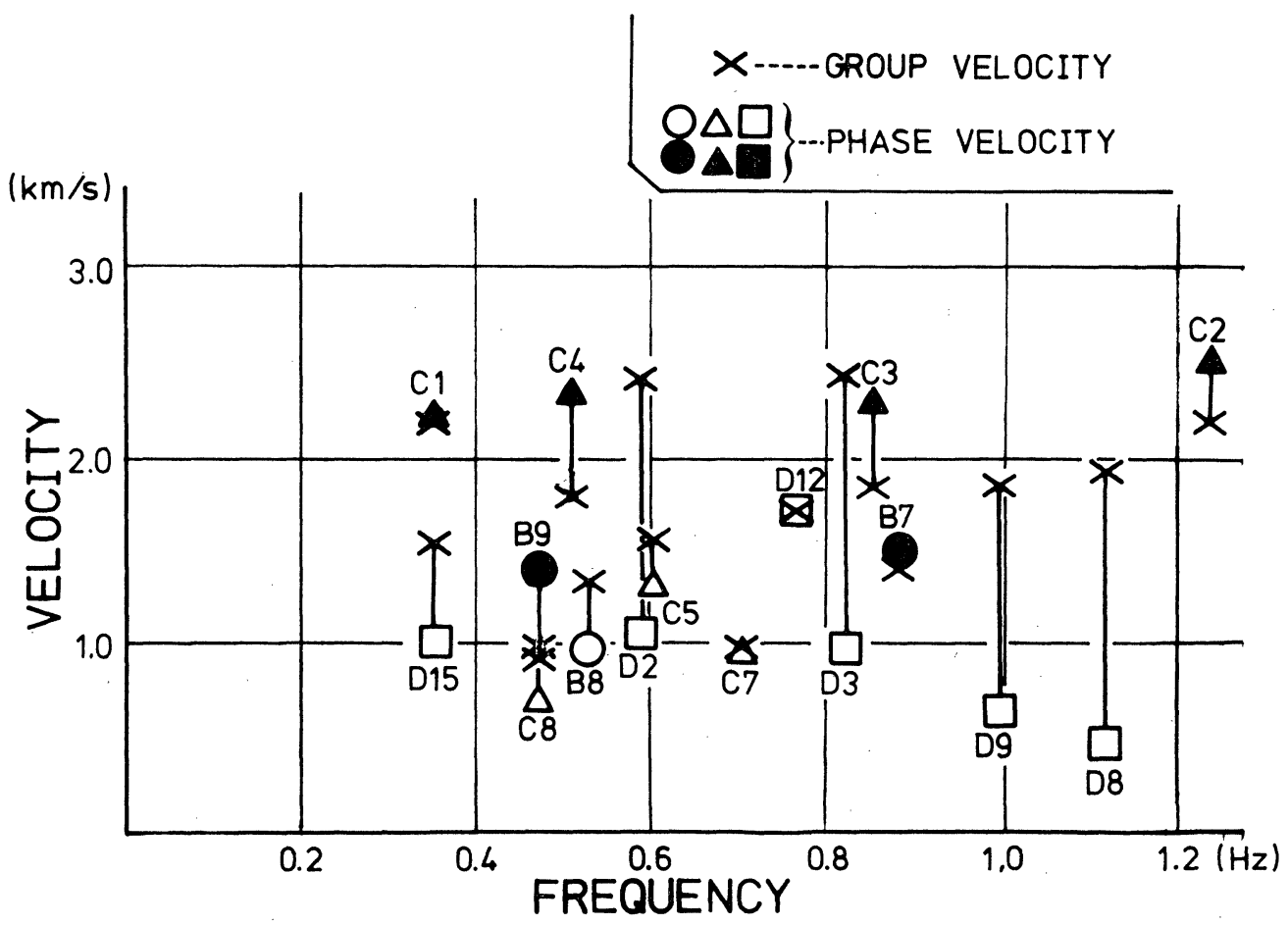

Fig. 15. Interrelation of phase and group velocities observed. Phase velocities denoted by solid symbols indicate normal relation between phase and group velocities. Open sym. bols imply abnormal situation; it could not be expected from laterally homogeneous crustal model. 
Table 2. Model of lateral heterogeneity of the uppermost crust

\begin{tabular}{cccccccc}
\hline Wavelet & $\begin{array}{c}\mathrm{V}_{\mathrm{I}} \\
(\mathrm{km} / \mathrm{s})\end{array}$ & $\begin{array}{c}\mathrm{V}_{\mathrm{II}} \\
(\mathrm{km} / \mathrm{s})\end{array}$ & $\begin{array}{c}\mathrm{V}_{\mathrm{m}} \\
(\mathrm{km} / \mathrm{s})\end{array}$ & $\theta$ & $\Delta \theta$ & $\begin{array}{c}\mathrm{L} \\
(\mathrm{km})\end{array}$ & $\begin{array}{c}\mathrm{L}^{\prime} \\
(\mathrm{km})\end{array}$ \\
\hline B 7 & 2.9 & 0.70 & 1.40 & $207^{\circ}$ & $27^{\circ}$ & 91.1 & 29.6 \\
B 8 & 2.9 & 0.45 & 1.30 & $215^{\circ}$ & $35^{\circ}$ & 91.1 & 20.2 \\
C 7 & 2.9 & 0.53 & 0.96 & $265^{\circ}$ & $20^{\circ}$ & 47.2 & 20.7 \\
C 8 & 2.9 & 0.56 & 0.96 & $263^{\circ}$ & $18^{\circ}$ & 47.2 & 22.2 \\
D 3 & 3.7 & 0.43 & 3.57 & $249^{\circ}$ & $22^{\circ}$ & 335.3 & 1.4 \\
& 4.3 & & & & & 7.4 \\
D 12 & 2.9 & 0.44 & 1.72 & $223^{\circ}$ & $-4^{\circ}$ & 335.3 & 42.8 \\
& 3.7 & 0.7 & & & & &
\end{tabular}

$V_{\mathrm{I}}$ : S-wave velocity of the outcropped besement in the area without sediment, $V_{\mathrm{II}}$ : calculated value of group velocity of normal modes for the area with soft sediment on the basement (see Fig. $12 \mathrm{~b}), V_{\mathrm{m}}$ : average group velocity between source and the array station, $\theta$ : direction of epicenter measured clockwise from the north, $\Delta \theta$ : difference of observed direction of wave approach and the direction of epicenter, $L$ : epicentral distance, $L^{\prime}$ : distance of the boundary of surficial sedimentary layer measured from the array.

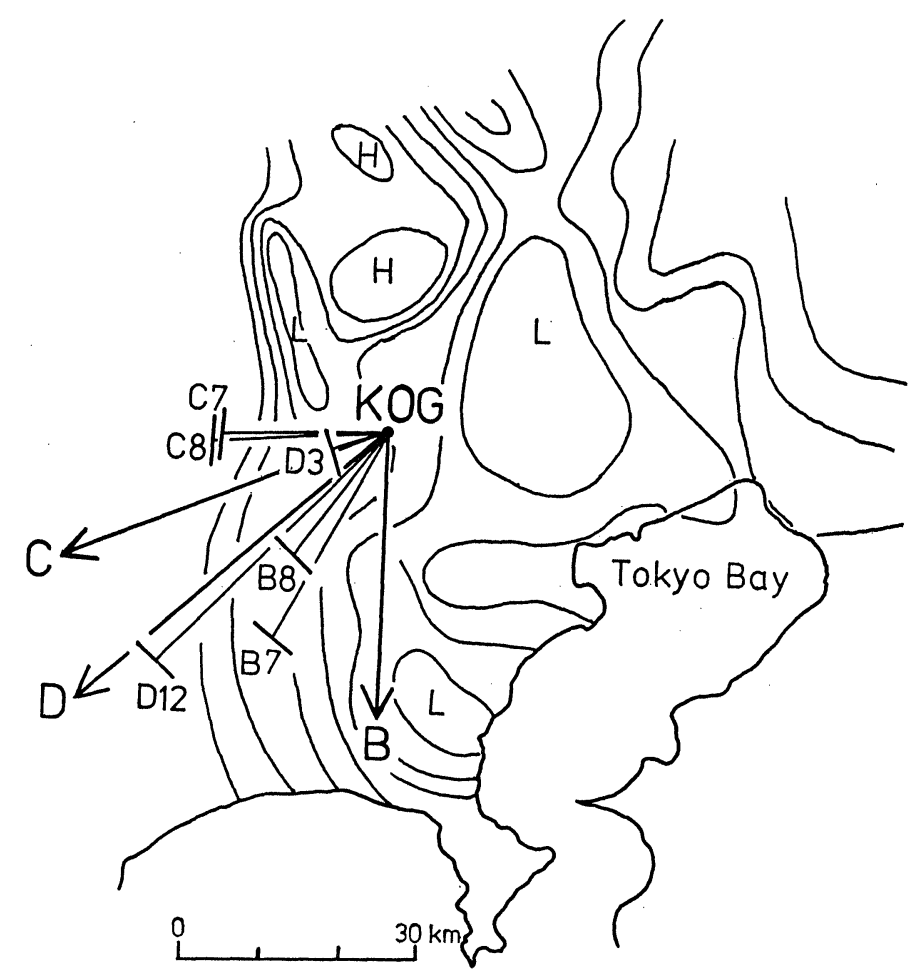

Fig. 16. The short bars indicate the boundary of surficial sedimentary layer, which are obtained through the analyses for the respective wavelets. Arrows indicate the directions of epicenters. Contour lines of the basement is after TADA (1983). 
C 共に, 時計回りの方向に偏つた到来方向を示す. 木下 (1986) は地震 $\mathrm{C} に$ 対し, 東京都府中 市周辺の観測網を用い，周波数波数・スペクトルを求めている. 本論に比べ長周期 $(5 \sim 10$ 秒）の波を対象としているが，波の到来方向がほぼ真西になる傾向は，本論と同等である．少 数例ではあるが, 震央距離が長い地震記録汪ど, 各波群の到来方向がばらつく傾向がある.

\section{§7. まとめと議論}

東京都小金井市付近で観測された中・強震動の周期 1 秒から 5 秒程度の波に着目し, 波の種 類の識別を中心課題として解析した. ランニングスペクトルによりエネルギーが集中する幾つ かの波群に分類し，その波群の位相速度を決定することから波の型を議論した。

1) 小金井市付近は堆積層厚が $2 \mathrm{~km}$ 程度であると考えられているが，明らかにこの堆積 層の影響を受けた位相速度 $1 \mathrm{~km} / \mathrm{s}$ 以下の波群が数多く見られた. 小金井市付近の構造を仮定 し, Love 波の分散曲線と比較した結果, 観測された位相速度は， $L_{1} ， L_{2}$ などの高次モード と解釈することができる．木下 (1986) は，観測された位相速度が分散曲線より系統的に大き い値を示す理由として傾斜層に依拠しているが, ABE and SUZUKI (1970) の結果から類推し て，傾斜層のみに依拠するには，理論と観測のくい違いが大き過ぎる．本結果においても多少 その傾向がある．地下構造モデルを手直しする必要が認められるが，データの蓄積を待つて議 論したい。

2）震央・小金井間の平均群速度と小金井にお抺る位相速度を比べると，群速度の方が高い 波群が多い．その程度は位相速度の低いもの程顕著である. 震央・観測点間の伝播方向の不均 質構造による. また波群の到来方向は震央方向からやや時計回りに偏る（地震 $\mathrm{B} ， \mathrm{C}$ ). AKI et al. (1958) は鎌倉に拈ける 3 点観測から，400 $500 \mathrm{~m} / \mathrm{s}$ 程度の遅い位相速度の波が存在す ること，遅い波ほど伝播方向が真の方向を向かないことを指摘している．さらに人工振源によ る波動の観測においても，到来方向が真の方向を向かない例も報告されている[金井・他 (1968)]. 波の伝播が表層の地下構造に大きく支配されるためと考えられる. 地震 Dは関東地方 が異常震域となるやや特殊な地震である．波群を細分化し過ぎたきらいがあるが，逆に複雑な 伝播過程の結果とも見ることがでさる．位相速度の高い反射波と見るべき波群の他に，位相速 度の低い, 堆積層で励起された波群も確実に存在する.

3）位相速度の決定には MS 法を中心的に用いたが，位相速度を決定し難い場合もあり， また手続きも煩雑な面があり, 必ずしも有効な方法とは言えない.また 3 点観測は, 位相速度 を決定するための, 最小の単位であり, スパンの大きさや, データが限定されているため, 強 震動を構成する波の一般的性質には，言及できない。しかし，今回の解析から，強震動に含ま れる中周期（1～5 秒）の波が，堆積層で励起された高次モードの Love 波として解釈するこ との可能性は指摘できたものと考兄る.

\section{謝辞}

本研究の開始時点より励むしを戴いた池上良平名誉教授 (東京学芸大学), 嶋悦三教授 (東 京大学地震研究所）に厚く御礼申し上げます. 金井清教授（日本大学生産工学部）には御教示 と励ましを戴き, 沢田義博電力中央研究所耐震研究室長には計器調達に便宜ははかつていただ いた．記して感謝の意を表します．研究費の一部は自然災害特別研究断「断層運動に拈ける短 
周期挙動と入力地震波の推定」（代表者佐藤良輔，課題番号 5602007) による.

\section{文献}

ABE, M. and Z. Suzuki, 1970, A Model-Seismological Study on the Propagation of Rayleigh Waves in a Medium with a Dipping Boundary between Superficial Layer and Basement, Sci. Rep. Tohoku Univ. Ser. 5, Geophys., 20, 1-25.

AKI, K., M. TsujIURA, M. HorI and K. Goto, 1958, Spectral Study of Near Earthquake Waves (1), Bull. Earthq. Res. Inst., 36, 71-98.

BLOCH, S. and A. L. HALES, 1968, New Techniques for the Determination of Surface Wave Phase Velocities, Bull. Seism. Soc. Am., 58, 1021-1034.

Bolt, B. A., Y. B. Tsai, K. Yeh and M. K. Hsu, 1982, Earthquake Strong Motions Recorded by a Large Near-Source Array of Digital Seismograph, Earthq. Engineer. Struct. Dyn., 10, 561-573.

CARA, M., 1973, Filtering of Dispersed Wavetrains, Geophys. J., R. astr. Soc., 33, 65-80.

Dziewonski, A., S. BloCh and M. Landisman, 1969, A Technique for the Analysis of Transient Seismic Signals, Bull. Seism. Soc. Am., 59, 427-444.

HARTzell, S. H., J. N. BRUne and J. Prince, 1978, The October 6, 1974 Acapulco Earthquake: An Example of the Importance of Short-Period Surface Waves in Strong Ground Motion, Bull. Seism. Soc. Amer., 68, 1663-1677.

HaSegawa, H. S., 1974, Theoretical Synthesis and Analysis of Strong Motion Spectra of Earthquakes, Can. Geotech. J., 11, 278-297.

IkEGAMI, R., 1963, On the Microseisms Observed at Koganei, Tokyo-A Preliminary Report-, Bull. Tokyo Gakugei Univ., 14, 99-105.

貝塚爽平, 1979, 東京の自然史〈増補第二版〉, 紀伊國屋書店.

金井 清・田中貞二・鈴木富三郎・長田甲斐男・吉沢静代・森下利三，1968，コンプレッサーによる 地盤振動の測定結果 (第 1 報), 地震研究所巢報, 46, 773-781.

茅野一郎, 1982,1982 年 8 月 12 日相模灘の地震 $(M 5.7)$ 飞よる被害等の概況, 第 578 回地震研 究所談話会講演.

木下繁夫，1985，傾斜層内に抢沪る SH 波の全反射伝播，地震 $2 ， \mathbf{3 8}, 597-608$.

木下繁夫, 1986, 格子型フィルタの地震観測への応用, 地震 $2,39,1-14$.

KUDO, K., 1978, The Contribution of Love Waves to Strong Ground Motions, Proc. 2nd Intern. Conf. Microzonation (San Francisco), 765-776.

KuDo, K., 1980, The Contribution of Surface Waves to Strong Ground Motions, Proc. 7th World Conf. Earthq. Engineer., 2, 499-506.

工藤一嘉・嶋 悦三， 1979，やや長周期地震波形の予測，第 16 回自然苂害科学シンポジウム，445446.

Mikumo, T., 1966, A Study on Crustal Structure in Japan by the Use of Seismic and Gravity Data, Bull. Earthq. Res. Inst., 44, 965-1007.

武藤 清・太田外気晴・菅野 忠・宮村正光・源栄正人・鎌形修一，1981，アレー観測による岩盤の 強震地動に関する研究, その 6 . 東松山に抢ける観測波形の周波数領域での相関性について, 日 本建築学会講演梗概集, 535-536.

太田外気晴・足立憲彦・越田 洋・稗圃成人，1981，岩盤アレー観測記録の解析，その 3 ，館山小ア レ一観測記録の解析, 日本建築学会講演梗概集, 543-544.

佐藤良輔, 1959, 分散曲線による地殼構造の決定について (III), 地震 2, 12, 191-201.

嶋 悦三・柳沢馬住・工藤一嘉・吉井敏起・一ノ瀬洋一郎 - 瀬尾和大 ・ 山崎謙介・大保 直人・山本 喜 俊 - 小口雄康・長能正武, $1976 \mathrm{a}$, 東京の基盤構造, 第 1 回 - 第 2 回夢の島爆破実験による地下深 部探查, 地震研究所彙報, 51, 1-11.

嶋 悦三・柳沢馬住・工藤一嘉・瀬尾和大・山崎謙介, $1976 \mathrm{~b}$, 東京の基盤構造その 2 . 第 3 回夢の島, 吉川町爆破実験に上る地下深部探査, 地震研究所巢報, 51, 45-61.

嶋 悦三・柳沢馬住 -工藤一嘉・吉井敏起・瀬尾和大 - 黒羽公明, 1978, 東京の基盤構造その 3. 第 4 回, 第 5 回夢の島爆破実験による地下深部探査, 地震研究所鲁報, 53, 305-318. 
Swanger, H. J. and D. BooRE, 1978, Simulation of Strong-Motion Displacements Using SurfaceWave Modal Superposition, Bull. Seism. Soc. Amer., 68, 907-922.

多田 堯, 1982, 関東平野の基盤構造と重力異常 (1) 一一基艋深度困——, 地震 2, 35, 607-617.

多田 堯, 1983, 関東平野の基盤構造と重力異常 (2) 一活断層の地球物理学的研究一, 地震 2 , 36, 359-372.

田中貞二・吉沢静代・大沢 㭌, 1979, やや長周期帯域に拈ける強震動の特性一一長周期低倍率地震 計記録の解析一一, 地震研究所罺報, 54, 629-655.

山水史生・高橋 博・後藤典俊・太田 裕, 1981 , やや深い構造の $\mathrm{S}$ 波速度 (III) 一一府中 $2,750 \mathrm{~m}$ 観測井に怙ける測定とまとめ一，地震 2, 34, 465-479.

YAMAZAKI, K. and H. IshII, 1973, Study of Phase and Group Velocities in a Dipping Layer Overlying an Elastic Medium Using Theoretical Seismograms, J. Phys. Earth, 21, 445-462. 